DR

536

M356g

MARSHALL

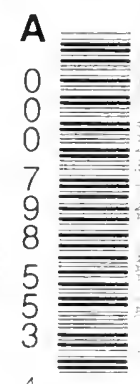

GREEK MANUSCRIPT DESCRIBING THE SIEGE OF VIENNA BY THE TURKS IN 1683

ornia

al 


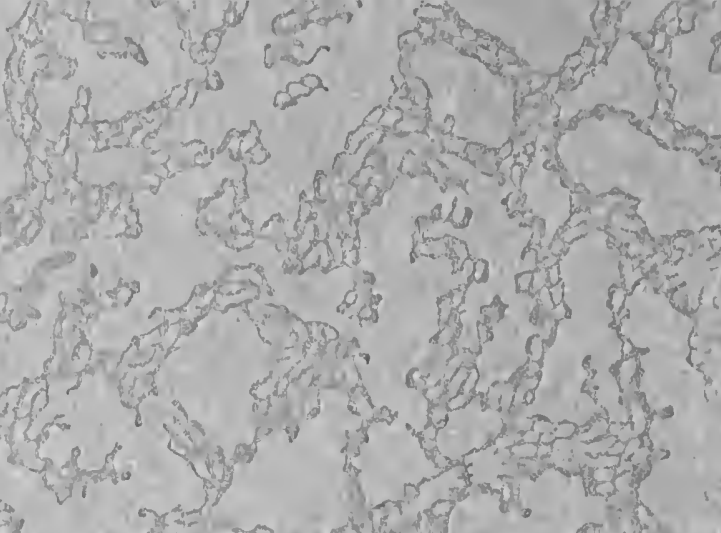





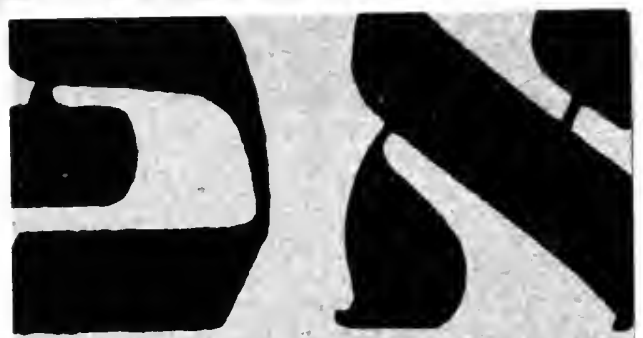

The Library

University of California, Los Angeles

The gift of Mrs. Cummings, 1963

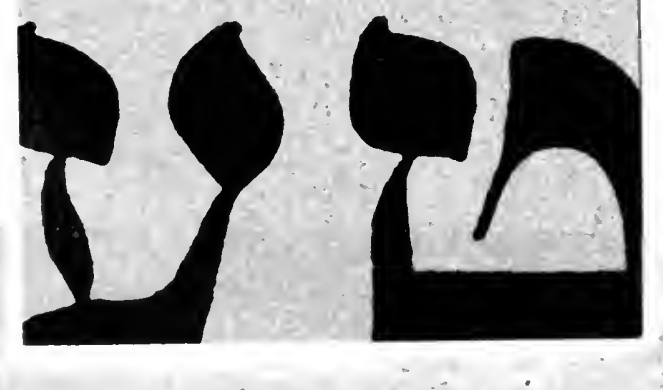




$$
\begin{aligned}
& D R \\
& 536 \\
& M 356 \mathrm{~g}
\end{aligned}
$$




\section{A GREEK MANUSCRIPT DESCRIBING THE SIEGE OF VIENNA BY THE TURKS IN 1683}

I THINK that those who take an interest in the history of the modern Greek language may possibly welcome a short note on a manuscript in the British Museum, which appears to me to be worth some attention, chiefly perhaps from the point of view of the part played by Greek culture in Roumania in the seventeenth century.

The manuscript in question is Add. MS. 38890 in the Department of Manuscripts, ${ }^{1}$ British Museum. It was acquired at Hodgson's sale, June 25, 1914, Lot 413, and is from the collection of the Hon. Frederic North, but was later in the possession of Richard Taylor. It is well written and presents but few difficulties of decipherment, and the number of errors is comparatively small. At the end the date of completion is given, viz. December 1686, and the place of writing-Bucharest.

I think the general character of the MS. will be best explained by the reproduction of the short preface prefixed to it. I give it here, together with a translation. The pages and lines are those of the MS., and spelling, punctuation and abbreviations are reproduced as they stand, though $I$ have not adhered to the very fluctuating use of the acute and grave accents.

\section{2}

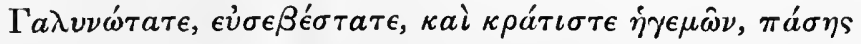

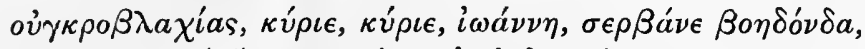

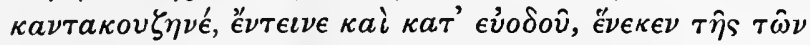
$\chi \nu \bar{\omega}^{\prime} \nu \pi i \sigma \tau \epsilon \omega \varsigma$.

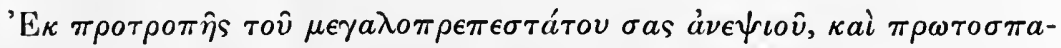

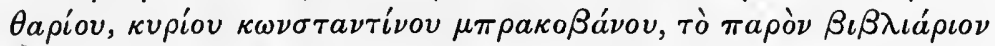

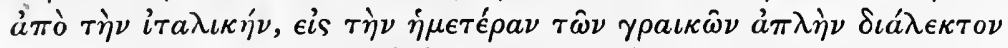

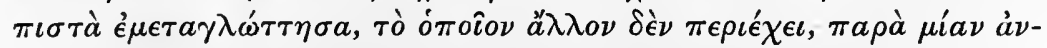

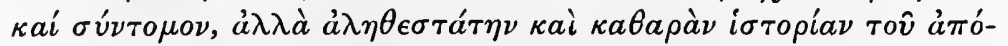

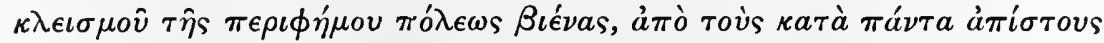

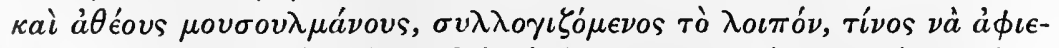

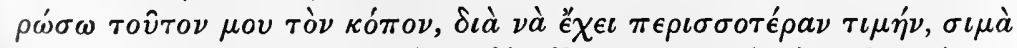

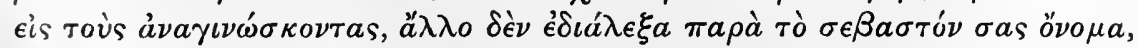

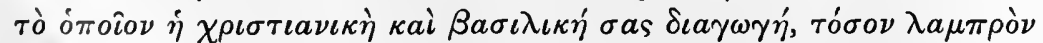

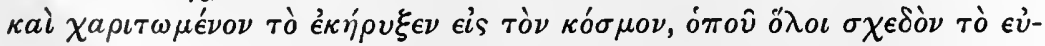

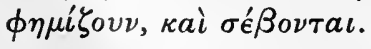

1 I have to express my thanks to Mr. ment of Manuscripts, British Museum, for J. P. Gilson and Mr. H. I. Bell of the Depart- drawing my attention to this manuscript. 
3

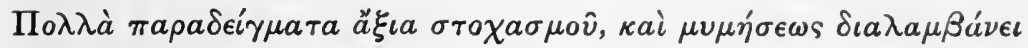

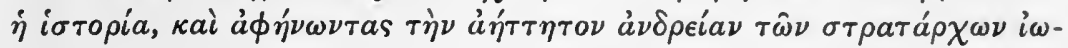

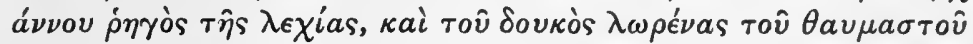
каi à

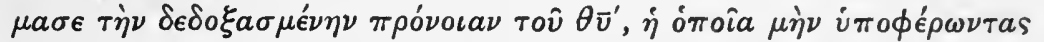

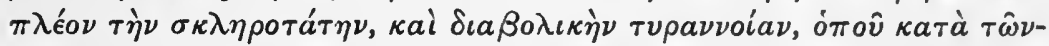

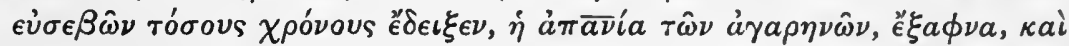

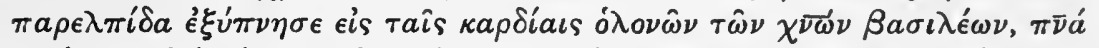

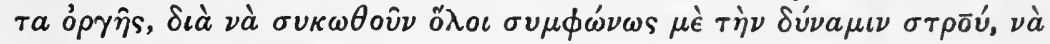

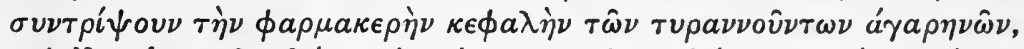

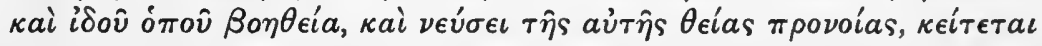

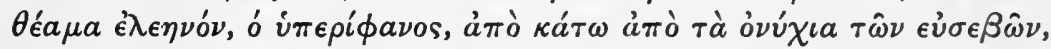

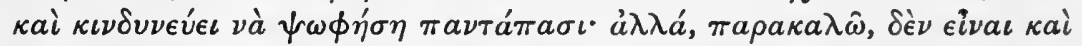

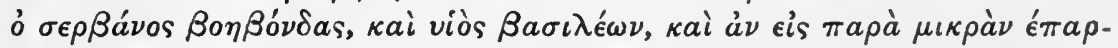

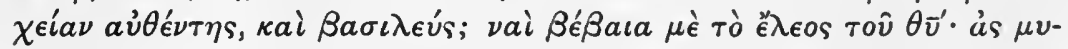

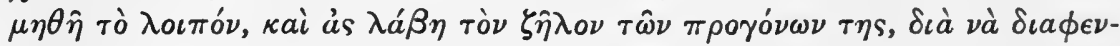

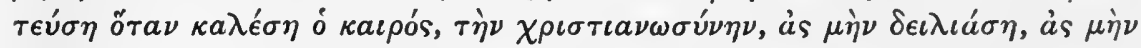

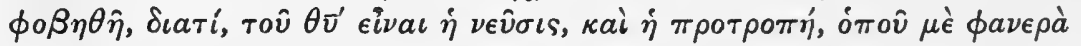

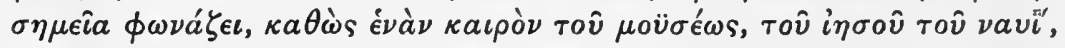

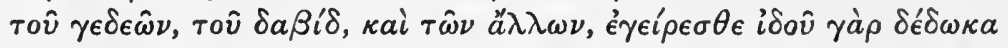

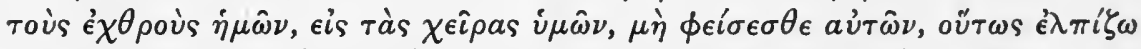

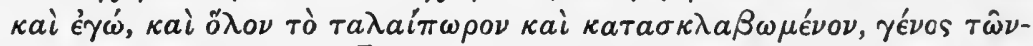

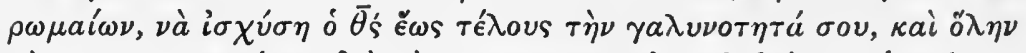

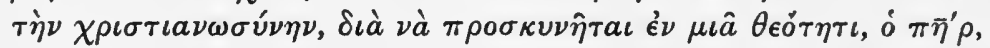

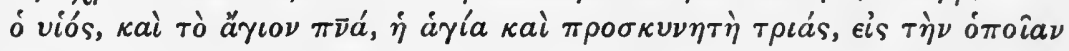

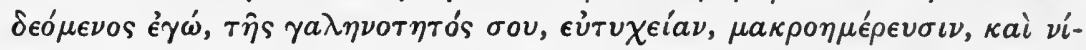

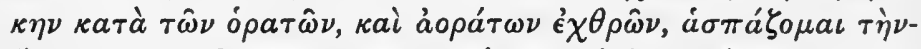

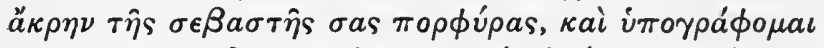

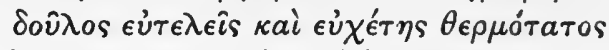

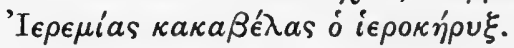

'Most Serene, Pious and Mighty Ruler of all Ugro-Wallachia, Lord John, Voivode, Servan Cantacuzenos, be strong and prosper in thy way on behalf of the Christian faith.

'At the instance of thy most illustrious nephew and protospatharios, Lord Constantine Bracovanos, I have translated the present little book from the Italian faithfully into our simple Greek dialect. It contains nothing but a brief, though perfectly true and clear account of the siege of the famous city of Vienna by the utterly treacherous and godless Mussulmans. So on considering to whom I should dedicate this work of mine that it may have the more honour in the eyes of the readers, I chose none other than your revered name, which your Christian and Royal bearing ${ }^{2}$ has proclaimed as so brilliant and gracious to the world, that nearly all acclaim and revere it.

\footnotetext{
${ }^{2}$ Cf. the description of Servan Canta. cuzenos in MS. No. 886 in the Hofbibliothek

at Vienna (quoted by Hammer, Gesch, d. J.H.S. - VOL. XLII. osm. Reiches, vi. (1830), p. 403, n.) : 'In 
'History treats of many examples worthy of reflection and imitation, and leaving aside the invincible courage of the generals John, king of Poland, and the wonderful and brilliant Duke of Lorraine, your Serenity should reflect upon and marvel at the glorious providence of God, which, no longer suffering that most harsh and diabolic tyranny which the Hagarenes in their inhumanity showed for so many years against the god-fearing, suddenly and unexpectedly aroused in the hearts of all the Christian kings the spirit of anger, that they should all with one accord arise in the power of the Cross to crush the poisonous head of the tyrant Hagarenes, and lo! with the help and at the beck of the same divine Providence, the proud lies low, a piteous sight, beneath the talons of the pious, and seemeth ready to perish altogether. But, I ask, is not Servan also a Voivode and a son of kings, yea, and a king to boot, even though he be lord over but a very small province? Yes, verily, by the mercy of God. Let him imitate, therefore, and take up the zeal of his forefathers, that when the time summons he may champion Christendom; let him not shrink, let him not fear, for the bidding is the Lord's, and the exhortation, which calls with clear signs, even as once to Moses, Joshua the son of Nun, Gideon, David and the others : Rise up, for, lo ! I have delivered our enemies into your hands, spare them not. Even so it is my hope, and the hope of all the hapless and enslaved race of the Romans, that God may strengthen your Serenity to the end and all Christendom, that the Father, the Son and the Holy Spirit, the holy and worshipful Trinity, may be adored in one Godhead. To which Trinity I pray on behalf of your Serenity for success, length of days and victory over your foes visible and invisible, and kiss the hem of your revered purple, and subscribe myself

' Your humble servant and fervent well-wisher 'Jeremias Cacaveisas the Preacher.'

I think we may be confident that this translation made by Cacavelas was never printed. It is nowhere mentioned in the accounts of Jeremias Cacavelas and his work, to which I now pass.

Jeremias Cacavelas, ${ }^{3}$ the translator of this monograph, was born in Crete. ${ }^{4}$ $\mathrm{He}$ became a monk, and in his zeal for learning travelled widely. He visited Asia Minor, and afterwards went to Leipzig, where he became acquainted with the teachers, and in particular with John Olearios, Professor of Greek. From Leipzig he went to Vienna, and from there wrote in 1670 a letter to

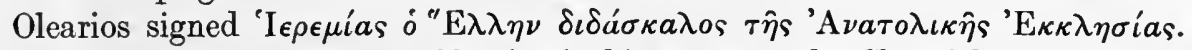
This letter was printed by Olearios in his notes to the Chronicle of Philip of Cyprus. The present MS. shows that Cacavelas was at Bucharest in 1686.

Valachia il principe moderno Serbano e uomo di gran spirito, potente e ricco per se stesso, amato dai Bojari e Grandi, ha gran parentela, due fratelli ... ha molti nepoti esperti, fra l'altri il Conte Brancovano che fu spesso Generale di queste provincie, persona di gran talenti.'

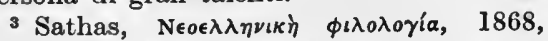
p. 383 f.; Xénopol, Hist. des Roumains, ii. 162, 173; Gröber, Grundriss der rom. Philologie, ii. 3, pp. 278, 283, 313, 393.

- I may mention that Prof. R. M. Daw. kins, who has been kind enough to go through my copy of the MS. with me, noted certain forms and turns of expression as Cretan before he knew that the translator came from that island. 
Later he moved to Jassy, where he is mentioned as Professor in the

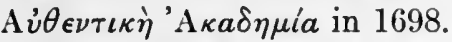

His residence in Wallachia brought him into contact with its subject prince. The translation is dedicated to Servan Cantacuzenos, Voivode of Wallachia (1679-1688), who was compelled to serve with the Turks in the siege of Vienna in 1683. In that campaign the Wallachians and Moldavians were not trusted to fight, but were employed in cutting timber ${ }^{5}$ and in bridgingwork, it may be said, which appears to have been done very unwillingly and ineffectually. ${ }^{6}$ Indeed the inefficiency of the Turkish bridges over the Danube seems to have contributed materially to the success of the relieving force. Servan Cantacuzenos left behind him a memorial of his devotion to Christianity in the form of an inscribed wooden cross. ${ }^{7}$

Constantine Brancovanos, called in our MS. Bracovanos, who succeeded his uncle Servan Cantacuzenos, is regarded as one of the most remarkable figures in Roumanian history. Something more will be said about him later on. Here it should be pointed out that one of his chief merits is to have reorganised and greatly enlarged the Greek school founded by his predecessor. I quote Xenopol on the subject of this school. ${ }^{8}$

'The first systematic organisation of public instruction in Greek was carried out in Wallachia by the Roumanian prince Scherban (Servan) Cantacuzenos. Though this prince scarcely had love for the Greeks and his policy towards them was even hostile, he nevertheless recognised the superiority of their culture, a thing which is the less surprising since then, as to-day, there was the same confusion between the modern Greeks and their celebrated ancestors. Del Chiaro tells us " that Scherban Cantacuzenos greatly favoured the development of teaching by giving splendid salaries to the Professors of the Greek language who taught grammar, rhetoric and philosophy to the children of the nobles." Scherban Cantacuzenos was the first to found a Greek school at Bucharest.'

We can thus understand why Cacavelas migrated from Vienna to Bucharest, and why Brancovanos prompted him to make the present translation. The appropriateness of its dedication to Servan also becomes clear. The fact is that Greek culture had been transferred from Greece proper to Wallachia and Moldavia. We know that Greek printing presses were set up both at Bucharest and Jassy. ${ }^{9}$

\footnotetext{
5 See a letter of Georg Chr. von Kunitz dated July 22, 1683: "Der Fürst aus Walachei (Fürst Cantacuzene) ist mit seiner Mannschaft beschäftigt, Hals über Kopf Bauholz zuzüfuhren, welches er alles in dem Wäldlein bei Schönbrunn schlagen und nach Wien ins Lager führen lässt; dieses, glaube ich, will man zu den Minen gebrauchen.' (Quoted by Camesina, Wiens Bedrängniss im Jahre 1683, p. 25, n. 6). Kunitz, who was Imperial Agent at Constantinople, was at the time a prisoner in the Turkish camp. See also Hammer, Gesch. d. osm. Reiches, vi. (1830), p. 403, 1.

6 Xénopol, p. 73 : 'Si les princes roumains, qui sympathisaient avec les chre. tiens, ne leur fussent venus en aido en di. verses occasions, au péril de leurs têtes, il est très probable que la ville n'aurait pu attendre le secours que lui amenait le roi de Pologne.'

7 Klopp, Das Jahr 1683, p. 237 ff. ; Camesina, op. cit., p. $134 \mathrm{f}$.

- Xénopol, ii. $173 \mathrm{ff}$.

- More will be found on the subject of Greek culture in Roumania in Xénopol's Istoria Ruminilor din Dacia Traianu, Vol. IV. p. $640 \mathrm{ff}$.
} 
Besides the letter to Olearios mentioned above, the only work of Cacavelas previously printed is a translation of Platina's De vita summorum pontificum made by order of Brancovanos in 1689 and a few poems. ${ }^{10} \mathrm{He}$ knew Greek, Latin, Hebrew and Italian, and was a noted preacher of the Gospel. This accounts for his present translation from the Italian, and also for his

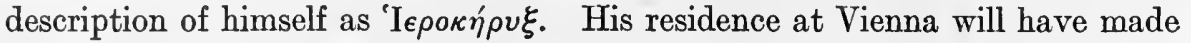
him specially interested in the siege, though I think it is clear that he himself was not present at it.

Later on Cacavelas migrated to the court of Constantine Cantemir in Moldavia, and taught Constantine's son Demetrios. In this connexion it is worth while to consider in somewhat greater detail the situation of these subject princes of Wallachia and Moldavia.

Their position was one of peculiar difficulty, since they formed as it were a buffer between the German and Turkish empires. ${ }^{11}$ Even after the defeat of the Turks before Vienna in 1683, Servan Cantacuzenos was not able to declare openly for the Emperor Leopold, in spite of the proofs of his leanings which he had given during the siege. After the great Imperial victory over the Turks at the battle of Harkány, near Mohács, in 1687, the Emperor sent a letter to Servan inviting him to join the Imperial side, and as a result the Voivode collected a considerable army with a view to adopting this policy. The Emperor held out various inducements, promising to recognise the right of the Cantacuzene family to the throne of Wallachia against an annual payment of 75,000 piastres, and even going so far as to offer to make Servan Emperor at Constantinople should the Turks be driven out of Europe. Despite the great skill which the Voivode showed in impressing the Austrians with a belief in his devotion to their cause, while at the same time lulling the suspicions of the Turks, the strong anti-German party at Bucharest (which included his nephew Constantine Brancovanos) brought his efforts to nought, and secured his removal by poison on October 29, 1688.

His successor, Constantine Brancovanos, reigned till 1714. He started as an anti-Imperialist, and inflicted a crushing defeat on the Austrian General Haisler in 1690. But in the next year he reversed his policy. His long reign was a continual effort to placate both Turks and Austrians, and in doing this he showed extreme ability. But in the end he was unable to ward off the fate which constantly threatened him. He was deposed by the Turks, removed to Constantinople and there executed together with his family.

We may now take a brief glance at the careers of the Moldavian princes Constantine Cantemir and his son Demetrios, the latter a pupil of Jeremias Cacavelas. Constantine reigned as Voivode of Moldavia from 1685 to 1693. He showed Turkish leanings, and as a result came after 1691 into collision with Brancovanos. From 1693 to 1711, Nicholas Mavrocordato, a Phanariote Greek, reigned at Jassy and was on terms of intimate friendship with Branco-

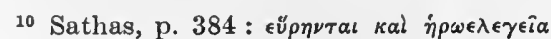

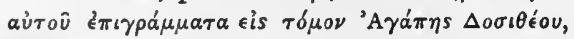

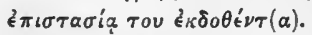

Cacavelas also translated the Greek
Liturgy into Roumanian (Gröber, op. cit.). 11 For what follows I am indebted to Xénopol, ii. p. $73 \mathrm{ff}$. 
vanos. He was replaced in 1711 by Demetrios Cantemir, ${ }^{12}$ owing to the desire of the Turks to bring about the fall of Brancovanos. But though installed as a pro-Turk, Demetrios was firmly convinced that the power of Turkey was on the wane and went over to the Russians, whose defeat on the Pruth he shared in 1711. It was with great difficulty that Peter the Great secured the personal safety of Demetrios and gave him an asylum in Russia.

Though the historical value of the MS. is not a question which strictly concerns the Hellenic Journal, I may perhaps be allowed to say a few words on this subject, especially since I have devoted a good deal of time to reading the contemporary and later literature dealing with the siege.

The Italian original from which Cacavelas made his translation was printed and published, though I shall have something to say on the strange omission of all allusion to it by specialist writers on the history of the siege. I owe my information to the courtesy of Sig. P. Zorzanello of the Biblioteca Nazionale di San Marco, to whom I sent extracts from the MS. His reply leaves no doubt that the original was the following book, a copy of which is in the library of San Marco at Venice. ${ }^{23}$ His description of it is as follows :-

' Raggualio historico della Guerra tra l'Armi Cesaree e Ottomane dal principio della Ribellione degl' Ungari fino l'Anno corrente 1683, e principalmente dell' Assedio di Vienna e sua Liberazione, con gl' incominciati progressi delle dette Armi Cesaree e Confederate. All' Illustriss. \& Eccell. Sig. Giulio Giustiniano cavaliere. Venetia, MDCLXXXIII, Presso Gio. Giacomo Hertz' (in $12^{\circ}$, pp. (xii), 215 e due tavole). These two plates are no doubt the illustrations from which Cacavelas made his two illuminations in the MS., viz. a portrait of the Emperor Leopold I. and a picture of the Turkish flag captured by John Sobieski and sent by him as a present to the Pope, Innocent XI. With regard to the author of the book Sig. Zorzanello supplies me with the following information from the Preface.

'Due Amici, uno somministrando le migliori notitie, e l'altro impiegandovi l'ordine, l'ornamento e qualche picciola reflessione, hanno condotta al suo fine quest' opera.'

Sig. Zorzanello then goes on to quote passages from the beginning and end of the book which correspond exactly to those in the MS.

The fact that the MS. is a translation of a published work certainly diminishes the interest of the document from the historical standpoint. Yet it seems to me a matter for surprise that an account, not merely of the details of the actual siege, but also of the general political circumstances from 1660 to October 1683, should, as far as I have been able to ascertain, have been entirely neglected by the specialist writers on the subject. The first edition of the book at all events is not included in Kabdebo's Bibliography of the two sieges. ${ }^{14}$ Nor can I find any allusion to it in the exhaustive works of

\footnotetext{
12 See also A. J. Evans in Encyclopadia Britannica', Art.' Roumania.' Demetrios in exile wrote a Descriptio Moldaviae in Latin.

${ }_{13}$ The book does not appear in the British Museum Catalogue.

14 Kábdebo (Heinrich), Bibliographie zur
}

Geschichte der beiden Türkenbelagerungen Wiens. Vienna, 1876. It would seem, however, that the following work mentioned by Kábdebo in his Supplement (p. 130, No. 339 ) is a second edition of the book.

- Ragguaglio della guerra tra l'armi 
Camesina ${ }^{15}$ and Klopp. ${ }^{16}$ There are, however, many indications that early writers on the subject, such as C. Contarini in his Istoria della guerra di Leopoldo I. contra il Turco (Venice, 1710), and the author of Theatrum Europaeum, Vol. XII. (Frankfurt am Main, 1691), and several others of approximately the same period, used the same sources as the authors of this Italian account of the siege and the circumstances attending it.

In view of this, it may not be out of place briefly to give my impression of the value of the book from the historical standpoint. In the first place it appears rather a remarkable achievement that the work, in spite of its obvious shortcomings presently to be alluded to, should have been printed and published in the same year as the siege, which ended as late as September 12. It is much more than a mere diary of the siege, which is the form taken by most of the works relating to the siege published in 1683 . It has the appearance of a political pamphlet put together somewhat hastily by writers who had access to good sources of information, but were so anxious to get the work out quickly that they were betrayed into a good many inaccuracies of detail. The general aim seems to be to foster harmony between the various elements of the Holy Roman Empire and the Poles with a view to the further prosecution of the war against the common enemy, the Turk and his Hungarian allies. Of the two policies open to the Emperor after the defeat of the Turks before Vienna-war with Louis XIV. or the crushing of the Turk-it is clearly the writers' business to recommend the latter. To this end the intrigues of Louis XIV. are almost ignored, as is the friction which existed between the various elements of the relieving force.

It is not surprising, in view of the shortness of the work, that its comprehensiveness is paid for by a good deal of superficiality. The attention given to detail is curiously unequal. One instance may be cited. The forces of the Elector of Saxony are described with considerable minuteness. Those of the Elector of Bavaria are practically ignored. In the case of the Poles the absence of such detail is compensated for by a general description of the elements of which the Polish army is composed.

The inaccuracies alluded to are chiefly those of dates. There is also a tendency to confuse minor military actions. In general, however, the work seems to me to give a clear picture of all the main features of interest (viewed, it is true, from the Imperial standpoint) belonging to the period with which the writers deal. I think that the specialist student would find the identification of the sources used for the work an interesting problem.

The Greek text, which includes many Turkish and other foreign words, should throw fresh light on the history of the Greek language in Roumania.

F. H. Marshall.

Cesaree et Ottomane da principio della ribellione degli Hungari sino l'anno corrente 1684, e principalmente dell' assedio di Vienna e sua liberatione con la vittoria di Barcan, aggiontovi in quest' ultima impres. sione la presa di Strigonia, molt' altre curiosita. In Venetia, 1684. $4^{\circ}$ '
15 Camesina (Albert), Wiens Bedrängniss im Jahre 1683 (in Berichte und Mitteilungen des Altertumsvereines zu Wein, Vol. VIII., 1865).

16 Klopp (Onno), Das Jahr 1683. Graz, 1882. 


\section{Additional Note.}

Bound up with the MS. are two inscriptions. They are in Roumanian. The first, on p. $\mathrm{i}$ at the beginning of the volume, is in Cyrillic character. The following transcriptions have been kindly supplied me by the Museum authorities on the understanding that they are to be regarded as provisional, since there is no expert there in this branch.

'Alu Kostandin Brankovénu V(oda) Spa(tar), skoasa de Jeremija Kakavela dasculu(l) şi egume(nul) Plavicénilo(r) dupe limba francésca pe limba grecésca şi scrisa de popa nekula : l(una) noe(mvrie) a(nu)l $a \bar{\chi} \bar{\pi} \zeta$.'

The second inscription, on $\mathrm{p} . \mathrm{v}$ at the end of the volume, is in both Roman and Cyrillic scripts and reads:

'Dic(emvrie) 15, 7195 arzintul de la steaesca (?) dramar(i) 1217.'

Though there is some uncertainty as to forms, there does not seem any doubt that the following are approximately correct translations :

1. 'To Constantine Brancovano Voivode and Spatar. Translated by Jeremias Cacavelas, Teacher and Abbot at the monastery of Plavicenii, from Italian into Greek. Written by the Priest Nicholas, November 1687.'

2. 'December 15, 1687. Payment for the copying (?), Drachmae 1217.'

Mr. L. C. Wharton of the Department of Printed Books, British Museum, has very kindly helped me in the interpretation of these inscriptions. ${ }^{17}$

F. H. M.

\footnotetext{
17 I may add that Cacavelas must have been still living in 1714 , for he was the author of a historical work on the wars between the Hungarians and the Turks, dedicated to Stephanos Cantacuzenos, who was Voivode of Wallachia, 1714-1716. E. Legrand in his Épistolaire grecque (Biblio. thèque grecque vulgaire, iv., p. xiii. (c)), mentions the following as included in the Catalogue of the MSS. in the Bibliotheque

du Métoque du Saint-Sépulchre at Con. stantinople:

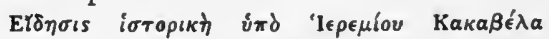

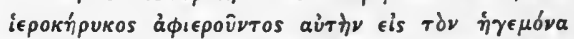

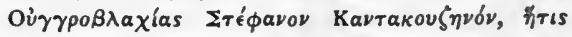

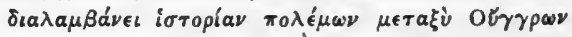

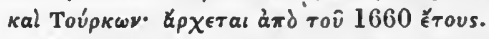

M. Legrand was unable to obtain access to this and other MSS.
} 


\section{Publications of the Society for the Promotion of Hellenic Studies.}

THE JOURNAL OF HELLENIC STUDIES.

Vols. I. to $\mathbf{S L}$, 3os. net each complete, or in parts 15 s. net each (except in the case of Volume IV., Part II., the price of which is $21 s$. net. VoI. XLI., Parts I. and II., 21 s. net each. Vols. I., Y., X., XX., XXXVIII, and XXXI. are not issued in parts. Vols. X'III., XIY, XXI. and XXII. are not sold apart from complete sets.) (l'rice to Mlembers and Subscribing Libraries. One Guinea per volume.)-Index IX. to XVI.. ${ }^{5}$. nes.

SUPPLEMENTARY PAPERS.

i. Excatatioxs at Megalopolis (ISgo-iSgI). By E. A. Gardexer, IV. Lorini,

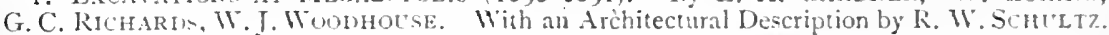
With Twelve I'lates, Folio, I\$92. 25s, net, (Price to Members, One Guinca for Nos. 1 and 2.)

2. Ecclesiantical sites in Inatria (Cilicia Tracliea). by A. C. Ileadean, With Two P'lates. Folio, 1893. 5s. net.

3. Plans and Drawings of Atuentax Buildings. By the late I. M. Mindeton. Edited by E. A. (rardirir. With Twenty-five Plates (Thirty-five Plans and Drawings). Sro, 1900. is. 6d. net. (Pice to Members, 5s.)

4. Excavations at ['mleaken Ix Melos. Conducted by the British Schonl at Athens. With Fortyone I'lates and 193 Illustrations in the Text. Inperial bro, 305. ne:, (Price to Members, $£ 1.1$

A CATALOGUE OF BOOKS IN THE LIBRARY OF THE SOCIETY FOR THE PROMOTION OF HELLENIC STUDIES. Imperial Sro, 5s. net.

Published by the Council and sold on their behalf by Macmillan and Co., Ltd., St. Martin's Street, London, W.C.2.

MACMILIAN \& CO., LTD., LONDON, W.C.2. 


\section{OXFORD BOOKS}

THE LEGACY OF GREECE. Edited ly R. W. Lirixgstose. Illustrat' !. Crown Sro. 7s. 6d. net.

CONTENTS:-Hellenism, by Gilbert Murray: Religion, by W. R. Inze; Philosophy, by T. Burnet; Mathematics and Astronomy, by Sir T. Heath; Biology, by D'Arcy W. Thompson; ledicine, by Charles Singer; Literature, by $\mathbf{K}$. W. Livingstone; History, by Arnold Toynbee; Political Thought, by A. E. Zimmern; Sculpture, by Percy Gardner; Arclitecture, by Sir Resinald Blomfield.

THE TRAGEDY OF GREECE. A Lecture delivered for the Professor of Greek to Candidates for Honours in Literae Humaniores at Oxford in May, 1920. Bv A. T. Torriber. Crown Sro. 2s. net.

I. The Work of Art. II. '1 he Plot. III. The Expression.

THE GREEK GENIUS AND ITS MEANING TO US. By R. W. Lningstone, Second edition, revised. 8ro. 7s.6d. net.

THE GENIUS UE THE GREEK DRAMA. Three Plays, being the Agrmennon of Aeschylus, the Antigone of Sophocles, and the Medea of Euripides, rendered and adapted with an Introduction by CrRIL E. RoBIsson. Crown 8ro, with short Notes and Illustrations. Paper cover. 2s. net.

Intended for reading aloud and for amateur theatrical production.

GREEK HERO CULTS AND IDEAS OF IMMORTALITY. The Gifford Lectures delivered in the University of St. Andrews in the year 1920. By Lewis Richard Fariell. Medium Sro. 18s. net.

Forms a continuation and supplement to the Vice-Chancellor's "Cults of the Greek States," though the difference of the subject has necessitated'a somewhat different inethod in the presentation of the facts.

NEW CHAPTERS IN THE HISTORY OF GREEK LITERATURE.

Recent discoveries in Greek Poetry and Prose of the Fourth and Following Centuries, B.c. Edited by J. U., P'owell and E'. A. Barber. Svo:' 10s. 6d. net.

These studies, by eleven contributors, of recent finds of Greek papyri will, it is hoped, make large additions to our knowledge of the history of Greek literature during the fourth and following centuries s.c. up to the beginning of the Roman era in the Greek world. Mlost of the material is here presented for the first time.

A HISTORY OF GREEK MATHEMATICS. By Sir Thomas Heati. Two volumes. Vol. I. From Thales to Euclid; Vol. II. From Aristarchus to Diophantus. With many Diagrams and Figures. Sro. Cloth gilt. 50s. net.

THE HOMERIC CATALOGUE OF SHIPS. Edited, with a Commentary, by Thomas W. Allex. Iledium Sro. 16s. net.

This book endeavours to prove the authenticity and age of the Catalogue of Ships, and by the aid of much literary and archae Jlogical evidence to show that it gives a true picture of the geography and political position of the Heroic Age.

OXFORD LEGTURES ON CLASSICAL SUBJEGTS. 8vo. 15s. nct, containing :

Four Centuries of Greek learning in England, by Ingram Bywater.

The Interpretation of Ancient Greek Literature, by Gilbert Mlurray.

Greek Tist rical Wringe, ind Am?'s ? $\mathrm{C}$

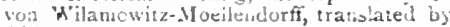

(iilbert Mntray:

Ille Egn: Virgil and Professor Richmond, by J. S. Phillimore.

Romances of Chivalty on Greek Soil, by J. B. Hity.

Developments in Textual Criticism, by A. C. Clark.

The Value of Byzantiue and Modern Greek in Hellenic Studies, by Simos Menardos.

Classical Ircharology in Schools, by Percy

Fresh lisht on Roman Bureaucracy, by $\mathrm{H}$. Stuart Jones.

On Aristotle as a Biologist, by D'Arcy W. Thompson.

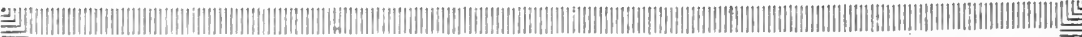 On receipt of a postcard stating the subjeits in which you are interested, Mr. Milford will gladly send you from time to time particulars of new and forthcoming books.

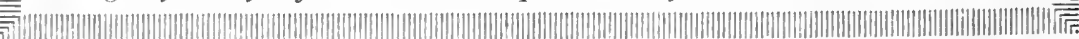



(x)

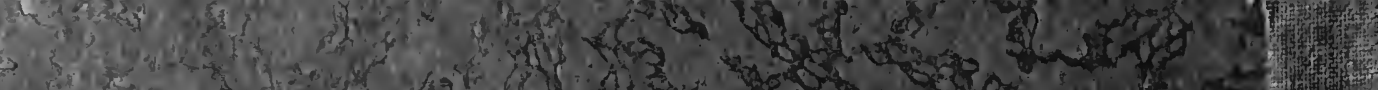

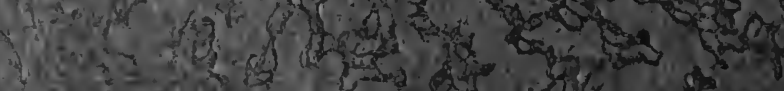

(3)

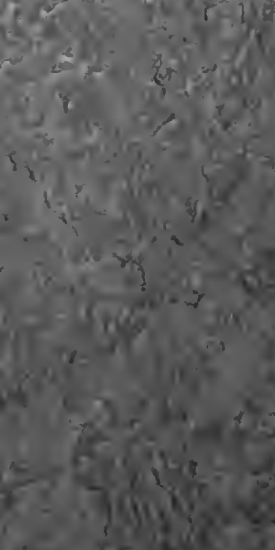
25.

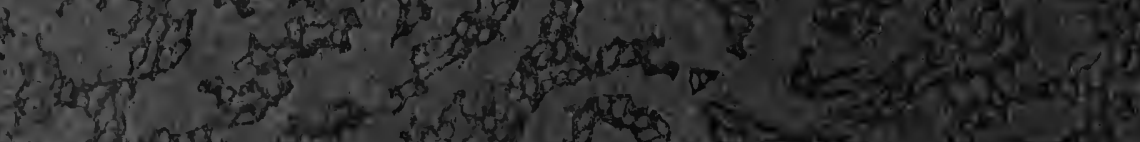
1.65

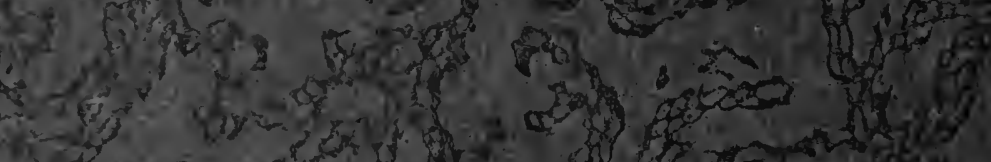
(5)

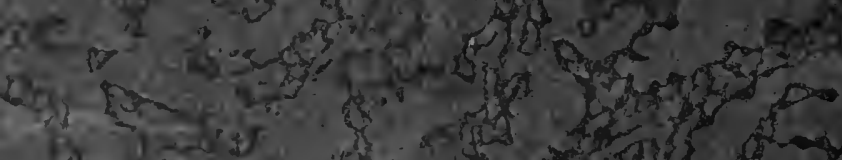

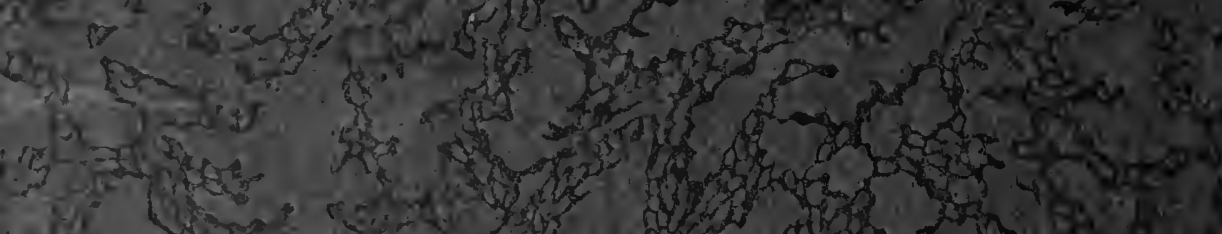

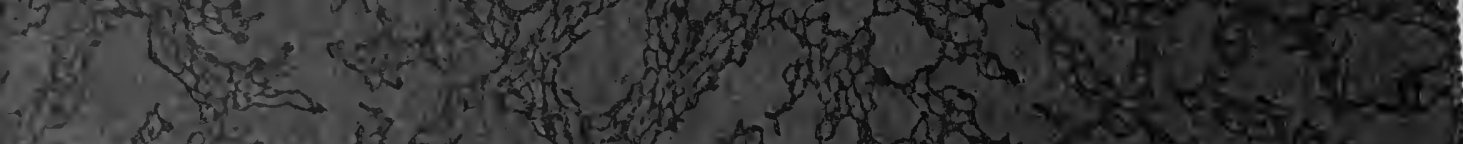
esh sing hed

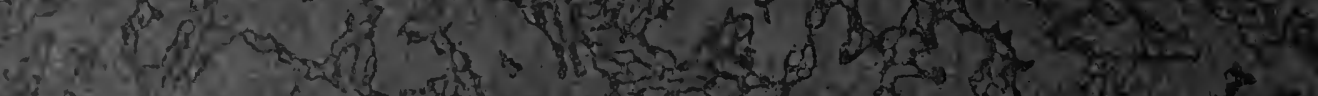
(x) 12. of of sect 18

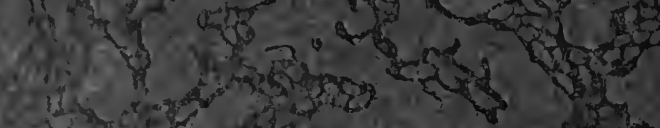

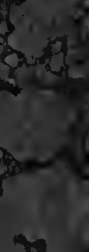
3. Universit Southe Libro

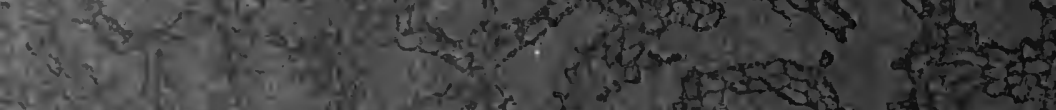

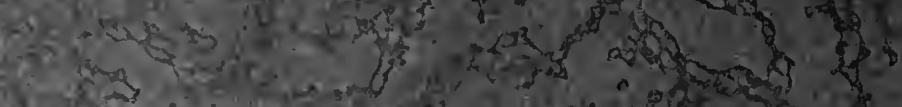

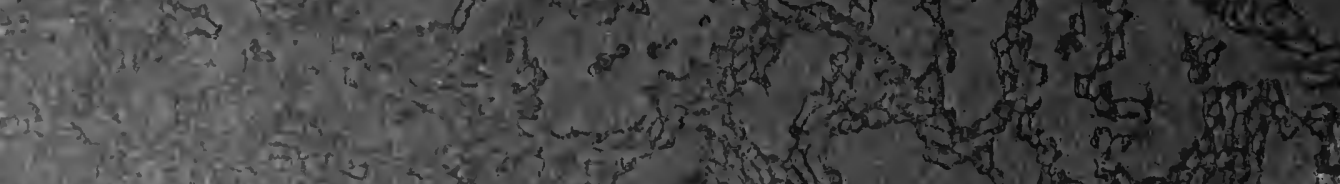

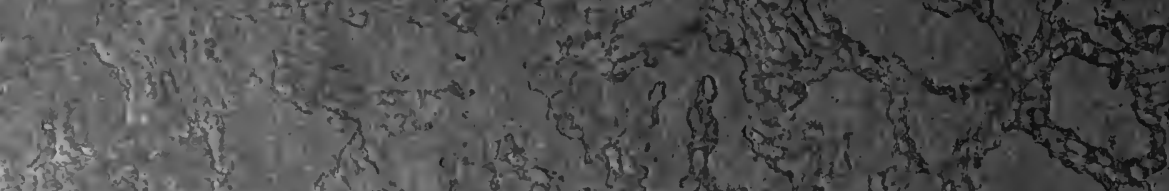
Q

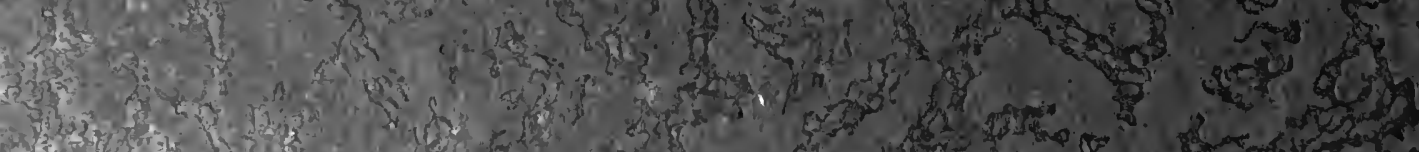

